\title{
Multicultural Conviviality, Diasporic Tension and Local Spaces in White Teeth
}

Bhawana Jain

\section{(2) OpenEdition \\ 1 Journals}

Electronic version

URL: https://journals.openedition.org/ces/4778

DOI: $10.4000 /$ ces.4778

ISSN: 2534-6695

Publisher

SEPC (Société d'études des pays du Commonwealth)

\section{Printed version}

Date of publication: 1 September 2016

Number of pages: 101-111

ISSN: 2270-0633

\section{Electronic reference}

Bhawana Jain, "Multicultural Conviviality, Diasporic Tension and Local Spaces in White Teeth", Commonwealth Essays and Studies [Online], 39.1 | 2016, Online since 05 April 2021, connection on 18 June 2021. URL: http://journals.openedition.org/ces/4778 ; DOI: https://doi.org/10.4000/ces.4778

\section{(c) $($ †) $\ominus$}

Commonwealth Essays and Studies is licensed under a Licence Creative Commons Attribution - Pas d'Utilisation Commerciale - Pas de Modification 4.0 International. 


\section{Multicultural Conviviality, Diasporic Tension and Local Spaces in White Teeth}

Different writers have contrasted critical reactions on London as being a multicultural city after the end of the British Empire. On the one hand, it is seen as a failure by critics such as Stuart Hall due to ethnic turmoil. On the other hand, Zadie Smith's novel White Teeth reconfigures "local" spaces/places as dynamic sites of multicultural "conviviality." This article addresses Smith's engagement with diaspora and identity by focusing on spatiality. The article also elucidates how a dense web of micro-spaces, places and "non-places," where a diasporic character is free to develop multiple affiliations away from the intricacies of the past (colonial)/ present (After Empire), depicts London in fiction through the use of hybrid writing. An emphasis will be placed on how London's urbanscape has transformed in the post-imperial context.

The chaos of globalization, triggered by rapidly criss-crossing boundaries and mass migration, is becoming propitious to deterritorialized and fragmented identities, shifting cultures and changing spatio-temporal realities. Consequently, the London metropolis is also being irreversibly altered in the twenty-first century, as are diasporas within it. Critics and writers have responded to this shift in varied and paradoxical ways. On the one hand, critics such as Stuart Hall define London as a "contact zone" (Pratt 6). Paul Gilroy's book After Empire: Melancholia or Convivial Culture? asserts how imperial dissolution has not only resulted in hostility towards blacks and immigrants in British urban centres such as London, but also in the failure to value the ordinary multiculture that has evolved in such spaces. Stuart Hall elaborates on this issue by focusing on the hostility against the non-white people of diverse histories and ethnic identities in his article, "The New Ethnicities" (1992). Moreover, in a recent interview, he demonstrates how the global framework along with the colonial past has created new pressures among different diasporas in Britain leading to regression, exclusion and violence:

[...] nothing really has changed. Some kids at the bottom of the ladder are deeply alienated, they've taken the message of Thatcherism and Blairism and the coalition: what you have to do is hustle. Because nobody's going to help you. And they've got no organized political voice, no organized black voice and no sympathetic voice on the left. That kind of anger, coupled with no political expression, leads to riots. (Hall 2012)

Stuart Hall's above comment sensitizes us towards co-presence of eroded social cohesion and its ensuing dangers in the form of racial turmoil, undermined diasporic identity, and the (im)possibility of convivial multiculturality in post-imperial London. Moreover, the historical event of gruesome riots resulting from the Rushdie controversy in the 1980s and the 1990s epitomizes the barriers separating Asian/ Black diasporas from the native population and hindering their cross-cultural encounters in mundane life and ordinary spaces/places. Other factors such as the inherent tension between the past (colonial) and the present (After Empire, being in the diaspora) complicate further diasporic identities and London's spaces/places in which they live.

On the other hand, other writers and critics belonging to diverse ethnic and sociocultural backgrounds have reconfigured the relation between the urban space of London, its native inhabitants and the diasporas, in a more positive and yet intricate way. For 
example, Homi Bhabha's seminal work The Location of Culture appreciates it for cultural negotiations and cross-cultural solidarities: "It is the city which provides the space in which emergent identifications and new social movements of the people are played out. It is there that, in our time, the perplexity of the living is most acutely experienced... [and] that we are in a position to translate the differences between them into a kind of solidarity" (170). Paul Gilroy's concept of "conviviality" refers to the popular culture of London "in which cultures, histories, and structures of feeling, previously separated by enormous distances, could be found in the same place, the same time: school, bus, café, cell, waiting room, or traffic jam" (Gilroy, Melancholia 70). Gilroy privileges human relationships in mundane life based on tolerance and openness in this post-imperial urbanscape.

Contemporary black British novelists have also engaged with this diasporic complexity of multicultural London. Zadie Smith's first novel White Teeth is an important landmark in this respect. As part of the new generation of black British writers, she has not only mapped the conflict in diasporic identity as well as the question of Britishness, but has also illustrated its transforming ramifications on the decentred and multi-ethnic London urbanscape, and vice versa. This essay elucidates how the new spatial framework, such as "non-place," (Augé, "Paris" 178) "chaos-monde," (Glissant 22) "scapes," (Appadurai 31) and Homi Bhabha's understanding of "third space," (Rutherford 211) constructs a new diasporic identity and engages with contentious issues such as the past and race in White Teeth.

According to various critics, Smith's inter-generational and multicultural novel White Teeth celebrates London's "post-racial" (Alibhai-Brown) environment and offers a "corrective to England's distorting mirror" (Jaggi). Marc Stein's assertion about black British bildungsroman also holds true for this novel as the latter engages with second generation diasporic characters who "have no predetermined route to choose," but "chart their journeys themselves" to "voice their identities," and symbolically "carve out space," enabling "the transformation, the reformation, the repeated "coming of age" of British cultures under the influence of 'outsiders within"” (Stein xiii). While these critics have focused on Smith's depiction of the diaspora and multiculturalism in London, this essay contends that the spatial reconfiguration also plays an important role to this effect. As the characters travel from one space to another, they trace geographical lines across London. The frequency of these spatial mappings in the novel asserts the importance of spatial-human interaction in examining the ingrained theme of the diaspora, identity and non-/be(longing). In addition, the depiction of the space/place/ non-place also illustrates Smith's use of a hybrid narrative technique. Vanessa Guignery in her essay "Zadie Smith's NW: the Novel at an 'anxiety crossroads?", also suggests the use of partial realist, modernist and postmodernist narrative techniques in Smith's latest novel $N W$ :

Ten years later, in $N W$, she develops modes and strategies partly indebted to realist, modernist and postmodernist practices. Such diversity calls for an examination of where, in 2012, she can be placed on the literary map, how she deals with the legacies of the past and what new lines she may be drawing for herself and for what she calls "the future [of] the Anglophone Novel."

The aforementioned lines assert Smith's hybrid narrative technique in $N W$ ten years after the publication of White Teeth. However, my paper suggests that this varying narra- 
tive technique is an important constituent of her writing on diaspora right from her first novel White Teeth. The emphasis of my article, hence, will also be on how Smith's hybrid narrative technique possibly depicts the culturally pluralistic British society.

The first part of this article explores relational understanding of the novel with different theoretical frameworks on spatiality. I illustrate how multiple examples of local spaces/places/non-places from the novel offer innumerable possibilities to deal with the diasporic identity which constitutes the basis of Smith's writing. The inherent conflict between the past/present and roots/hostland is an important constituent of diaspora and this black British bildungsroman. The next part deals with structural analysis of the novel so as to re-examine complex issues such as race and the past, sometimes hindering the conviviality of the spaces/places/non-places inhabited by the diasporic characters. The main focus of this article will be on how Smith's depiction of diverse spaces counters these diasporic and the post-imperial tensions, and re-affirms a vision of multicultural conviviality in London.

\section{Non Places}

White Teeth is divided into 20 chapters, each focusing on different characters whose lives frequently transgress the imaginary borders/divisions as they travel from one locale to another across London. Each episode is marked by a specific spatial experience and the use of a different narrative mode.

The first chapter opens in Cricklewood Broadway which could be seen as a lively "non-place" where travellers throng "[...] in order to go other places via the A41," (4) attributing to it a transitory physical quality. The French critic Marc Augé defines "nonplace" as a place of transit, "the spaces of circulation, communication and consumption, where solitude coexists without creating any social bond or even a social emotion" (Augé, "Paris" 178). Examples of a "non-place" are as follows: a motorway, a hotel room, an airport or a supermarket. In contrast, Marc Augé defines place or "anthropological place" as a familiar, localized, organic and a meaningful site which evokes a sense of attachment, memories and belonging. It is "a space where identities, relationships and a story can be made out" (Augé, City 8). The setting Cricklewood (a "non-place") in the novel is surrounded by restaurants, bars and slot-machine emporiums, making it a site of spectacle, socialization and excitement. Alternatively, it is a site of alterity where trash from local restaurants and shops, "discarded armchairs, strips of carpets," (WT 4) greasy minicabs, daily bloodshed of the halal butchers, flying vermin and the infestation by pigeon excrement create an incongruous uncanny picture of filth and disorder. The third-person omniscient narrator articulates the gloomy other side of the London backdrop, "this nasty urban street," evoking consequently the frustration and disappointment of its denizens. One such character is Archie, an Englishman. In an article, Taryn Beukema succinctly sums up his conflicted masculinity in the post-imperial landscape:

Archie Jones is a born and bred Englishman, and is the antithetical representation of "masculinity" as defined by England's colonial empire [...]. Archie is the epitome of rootlessness and indecision. Unable to live up to the ideals of reason and rationality at the heart of English masculinity (every decision he makes is based on the flip of a coin), Archie represents a "failed" masculine identity. (Beukema 4) 
This disoriented protagonist is driven to attempt suicide due to his failure to conform to the rules imposed by this non-place as well as Englishness at the beginning of the novel. At this moment, the omniscient narrator permeates the mind-set of the protagonist evoking a mix of humour and pity:

But even as his breathing became spasmodic and his lights dimmed, Archie was aware that Cricklewood Broadway would seem a strange choice. Strange to the first person to notice his slumped figure through the windscreen, strange to the policemen who would file the report [...]. Squeezed between an almighty concrete cinema complex at one end and a giant intersection at the other, Cricklewood was no kind of place. It was not a place a man came to die. It was a place a man came in order to go other places via the A41. But Archie didn't want to die in some pleasant, distant woodland [...] The way Archie saw it, country people should die in the country and city people should die in the city. Only proper [...]. (3)

The heterodiegetic narration in these lines constantly shifts focalisation from the psychological insight to the nuanced description of the topos. The free indirect thought technique gets into the character's troubled mind, "Archie was aware that Cricklewood Broadway would seem a strange choice," to see how this non-place imposes a sense of detachment and "solitary contractuality" (Augé, Non-places 94). The narrator succinctly sums up Archie's life: "this nasty urban street where he had ended up, living alone at the age of forty-seven, in a one-bedroom flat above a deserted chip shop" (WT 3). Archie is reduced to a victim of this non-place. Archie's condition, here, is reminiscent of Beckett's protagonists from the plays such as Waiting for Godot and Endgame, who develop a nihilistic outlook of the world. Archie succumbs to existential angst after being unable to build any meaningful relation at home in this London non-place. The postmodernist vein can be found both in the aesthetic sense of this "non-place" and in the kind of historical consciousness that Archie enacts as he struggles with his own spatio-temporality. However, if this "non-place" and his failed masculinity are responsible for Archie's despair, loneliness and attempted suicide, then it also becomes pivotal in saving and offering him a new hope to live as it is re-configured into an anthropological "place." As a paradoxical place, it evokes Archie's sense of belonging and attachment to it: "The way Archie saw it, country people should die in the country and city people should die in the city." Hence, it becomes both a site of Archie's alterity as well as connection.

Unlike fictional places like Thomas Hardy's Wessex or Faulkner's Yoknapatawpha, Cricklewood is a locality of North-West London where Zadie Smith spent her childhood. The use of semi-autobiographical elements in the depiction of this place elicits the author's own connection to it. In other words, Smith uses her first-hand experience in delineating the every-day lives of her characters in this local "non-place" and to demonstrate how London has transformed into a multi-ethnic city after the end of the British Empire.

Stuart Hall's writings bear testimony to the strife and violence among and within multicultural communities and individuals in this alien London metropolis. Such is also evident in the depiction of separate ideologies and limiting views that divide and create discord among the victors and vanquished of the Second World War, religious fundamentalists belonging to different religions, race and ethnicities, Kevin and Fate group members, among others in the novel. These differences also hamper relationships between Millat and Magid, Joshua and Marcus, and Samad and Dr. Perret. Millat joins an Islamic fundamentalist youth group KEVIN due to racism even though he is not a 
religious person. In 1989, when the Rushdie affair was rife, he goes to Bradford to take part in protest against The Satanic Verses. Alsana is so enraged by this that she subsequently burns his books, records, clothes, etc. Her motto is: "Either everything is sacred or nothing" (164). Millat's intolerance and ignorance is unacceptable to her. However, in spite of their different viewpoints and conflicts, all these characters come together for a common purpose in the climax at another "non-place." The latter is conceived as a site of cross-cultural encounter, a space of opportunities, and freedom. No matter which different and irregular trajectories are taken by the characters, all converge in the same "contact zone," a virtual zone,

[...] the final space. A big room, one of many in the Perret Institute [...] a corporate place, a clean slate; white/ chrome/ pure/ plain (this was the design brief) used for the meetings of people who want to meet somewhere neutral at the end of the twentieth century; a virtual place where their business [...] can be done in an emptiness, an uncontaminated cavity; the logical endpoint of a thousand years of spaces too crowded and bloody. $(517-8)$

The physical description of high-technology engineering and architecture of this nonplace, in the penultimate chapter titled "the final space," "white/ chrome/ pure/ plain (this was the design brief)," is symptomatic of "hyperreality." In technologically advanced postmodern societies, the human being is reduced to the hyper-subject who is "fascinated and entangled with the technologies and images" and his contemporary objective world is "replaced by the brute world of juxtaposition, repetition, momentum and the seduction of ready-made packages of meaning or signs" (Pile and Thrift 23). This also is Zadie Smith's twenty-first century vision of London, a kind of rootless cosmopolitan urbanism, where life is in a ceaseless flux due to a "logical endpoint of a thousand years of spaces too crowded and bloody" (Smith, White Teeth 428). Hence, London is seen as transformed into a cosmopolitan centre at the beginning of the twenty-first century. Moreover, this "non-place" is also marked by the fluidity of "scapes" (Appadurai 31). Arjun Appadurai's "scapes" refers to the irregular trajectories taken by the people across the world, including tourists, immigrants, refugees, exiles, and other mobile groups. In his influential essay "Disjuncture and Difference in the Global Cultural Economy," (1990) Appadurai asserts that the mutual interaction of global and local processes in a contemporary scenario creates a new Glocal culture, which is a complex of overlapping and ruptured constellation. Furthermore, Appadurai explains that the new global cultural flows occur in and through growing disjunctures and conjunctures among ethnoscapes, technoscapes, financoscapes, mediascapes, and ideoscapes. Similarly, in this mosaic "final space" of the novel, people irrespective of race, culture, class and religious differences, "Nazi scientist, Islamic fundamentalists, animal rights activists, Jehovah's Witnesses, and the Joneses, Iqbals, Chalfens, 'Nigerian cleaning lady,' 'Polish night watchman," come together, in spite of their diverse trajectories, to participate in the future mouse exhibition. Hence, the author delineates a picture of ultramodern and culturally hybrid London.

Additionally, Arjun Appadurai advocates chaos theory in the global scenario. Martinican writer Edouard Glissant also observes that the global world is marked by rapid

1. For Jean Baudrillard, "hyperreality" stands for the contemporary experience. It is a particular mode of experiencing the world found within high technology consumer societies. This is a mode of representation, a sign without an original referent. See Baudrillard 12-4. 
cross-cultural interactions, the breakdown of standard rules and uniformity, and yet it does not lead to incomprehensible turbulence. He conceptualizes the term "ChaosMonde" to delineate this human experience of space:

I use the expression Chaos-Monde to refer to the current cultural clash of so many cultures that take in or reject one another, that vanish and yet, survive, remain the same or become transformed either slowly or with lightning rapidity; the burst of brilliance, the splitting apart - the principles of which we have not even begun to grasp and the operation of which we cannot predict. $^{2}$

This concept highlights the clash of cultures in the globalized world and the consequent unpredictable results, not always convivial or fraught, out of such a contact. In the final scene of the novel, when people with different objectives and perspectives huddle together, the chaos and hotchpotch is seen. This muddle is further compounded by the use of unconventional narrative form and syntactical disorder, which is also postmodern per se:

A room/furniture/Britain (that was the brief: a new British room, a space for Britain, Britishness, space of Britain, British industrial space cultural space space); [...] and they know what is meant by national identity? symbols? paintings? maps? music? airconditioning? smiling black children or smiling Chinese children or [tick the box]? world music? shag or pile? Tile or floorboards? plants? running water? they know what they want, especially those who've lived this century, forced from one space to another like Mr. De Winter (né Wojciech), renamed, rebranded, the answer to every questionnaire nothing space please just space nothing please nothing space. (518-9)

The omniscient narrator brings together random slices of information, simply piling them up with a sense of immediacy. The unpunctuated words and abandonment of syntax reinforce fragmentation and jumbling. This disjointed narrative draws attention to the visual spaces on the page, a metaphor for the gaps or pieces that are deliberately missing and omitted. Because the narration is not total, the reader becomes involved in the process of imaginary recreation himself. Repetition of words, "nothing space please just space nothing please nothing space," evokes contingent and complex human-space relationship in the twenty-first century urban context. Besides, human identities emerge as fluid, deterritorialized and in the process of becoming. New commercial language positions the human being as an object and a consumer product, "Mr. De Winter (né Wojciech), renamed, rebranded." It is the newly designed architectural non-place where an immigrant, as the foreign name Wojciech suggests, is committed to assimilating and endorsing Britishness instead of nurturing separatist philosophies or even diverse cultural specificities.

The depiction of these minute "non-places" emphasizes the necessity to explore the link between everyday negotiations and spatial reconfigurations from a new perspective. The novel describes a number of "non-places," where there is a possibility to break away from the colonial history based on the dichotomy of self/other, superior/inferior and center/periphery. These are also perceived as the sites where ideologies and identi-

2. Original text is as follows: 'J'appelle Chaos-Monde le choc culturel actuel de tant de cultures qui s'embrasent, se repoussent, disparaissent, subsistent pourtant, s'endorment ou se transforment, lentement ou à vitesse foudroyante; ces éclats, ces éclatements dont nous n'avons pas commencé de saisir le principe ni l'économie et dont nous ne pouvons pas prévoir l'emportement." Glissant 22. English Translation taken from online source. 5 June 2015: <http://scholarlyrepository.miami.edu/cgi/viewcontent.cgiarticle $=1131 \&$ context $=$ anthurium $>$. 
ties are no longer fixed or rooted but routed. A number of minutely described granular local urban spaces throughout the novel complement further the thesis of this article.

\section{Other Spaces / Places: Contact Zones}

Public spaces of encounter such as the school, pub, restaurant, street and playgroud in White Teeth delineate the everyday lives of London's inhabitants through realism and hybridity. These dynamic and complex micro-places become the series of narrative signposts in the text where the diasporic characters either choose to belong in or navigate through a complex cultural multiplicity instead of being entangled in its clutches. Here, they enjoy freedom of choice to permanently reinvent themselves and to establish multiple affiliations.

In one episode, Smith employs realism to draw attention to the ongoing debate in London among people of different races and cultures. The discussions on Mangal Pande (Samad's great-grandfather), which are influenced by English colonialism, reveal Samad's ethnocentrism. This principal character strictly defines himself by his religion, family background and the experience of being an outsider in the aftermath of British Empire. Caught in a conflict between being here (London) and belonging there (Bangladesh), he tries to save his son Magid from a failed diasporic life. He tells Archie:

I looked at my beautiful boys [...] and my heart cracked - no, more than this - it shattered. It shattered into so many pieces and each piece stabbed me like a mortal wound. I kept thinking: how can I teach my boys anything, how can I show them the straight road. (67)

Samad feels that both his body and heart are irreparably wounded by being in the diaspora. It is difficult for him to belong in London, an alien and ex-colonial centre. But, at the Irish pool hall, he feels that he can leave behind his ethnicity, past and racial differences, and come together with others as an individual: "[It] is the kind of place family men come to for a different kind of family [...]. This is Archie's and Samad's home away from home, for ten years they have come here between six (the time Archie finishes work) and eight (the time Samad starts) to discuss everything" (183). O'Connell's is a hybrid place which is "neither Irish nor a pool house," but rather an "Irish pool house run by Arabs with no pool tables" (183). Paintings of racehorses, fragments of the Quran hanging on its carpeted walls, the decoration of an Irish flag and a map of Arab Emirates together indicate cultural heterogeneity and the eclectic. O'Connell's is run by Iraqi Abdul Mickey, whose hybrid name reflects the cultural métissage. This place rejects any claims of essentialist identities structured around the fixed notions of home, roots and the past. It allows for a shared identity/culture based exclusively on friendship, experience and discussions. Similar interests help both Archie (a white British man) and Samad (Asian immigrant) to be tolerant and open towards the others, and move towards a common future. Here, neither ethnic background nor color defines who one is; rather "it is necessary here to earn one's position in the community; it takes years of devoted fucking around, time-wasting, laying-about, shooting the breeze [...] You need to know the place" (183). Here, mundane life is delineated in all its veracity through colloquial language and humorous tone to portray the popular culture of contemporary London. The minute precision with which every detail is delineated, including how clients savor "chips, eggs and beans, chips and beans, or beans, chips, eggs and mushrooms" (183-4) incites a shared sense of belonging through "culi- 
nary citizenship" (Mannur 20). A convivial local culture is, therefore, constructed which helps both immigrants and natives to overcome their sense of personal loss wrought by dislocation and changing times. Traditional and confining boundaries are disrupted and communal bonding, irrespective of race and nationality, is encouraged in this place.

A vision of the convivial could also be seen in Homi Bhabha's understanding of the "third space" (Rutherford 211) and hybridity. He posits hybridity as a form of liminal or in-between space of negotiation and appropriation which is productive and offers new possibility, and what he terms the "third space." It is an "interruptive, interrogative, and enunciative" (Bhabha, Location 37) space for new cultural meaning and production blurring the limitations of established categorisation of race and identity. This notion is constantly employed by Smith through a number of reconfigured little spaces. The playground is emptied out of all history, background, and any other specificity, except that as a "third space":

It is only this late in the day that you can walk into a playground and find Isaac Leung by the fish pond, Danny Rahman in the football cage, Quang O'Rourke bouncing a basketball, and Irie Jones humming a tune [...]. It is only this late in the day and possibly only in Willesden, that you can find best friends, Sita and Sharon, constantly mistaken for each other because Sita is white (her mother liked the name) and Sharon is Pakistani (her mother thought it best - less trouble). (281-2)

The playground is open, a dynamic and inclusive micro-space, rather than being closed and static. It is a convivial meeting point for children with different, complex histories, and diverse ethnic roots. Their names also suggest hybridity: "Danny Rahman," "Quang O'Rourke," "Sita" and "Sharon." Here, these children cross the boundaries separating them from each other after the imperial dissolution. They establish new solidarities and cultural routes, and enjoy freedom from the baggage of the past. The playground celebrates the ethos of the multicultural conviviality and shatters any notion of sociocultural dissension and turmoil. It redefines nation and Britishness in the global era.

The particularity of Zadie Smith's writing in promoting Britishness, a culturally pluralistic concept, through the "local" is again evident in the delineation of Glenard Oak school. The crazed atmosphere of the nightmare also depicts her intrinsic turmoil and her inability to provide a rounded account of her trauma even after decades have elapsed. This school celebrates the spirit of heterogeneity: "Everyone at Glenard Oak was at work: they were Babelians of every conceivable class and color [...] 67 different faiths, 123 different languages [...]" (292). All racial, religious and linguistic differences, which are often the reason for conflict and violence, converge here. New subjects and holidays are introduced to ensure that minority cultures are also accommodated and recognized. In fact, Samad argues with the school authorities about the Harvest festival, which he dismisses as a pagan festival: "What is all about the Harvest festival? What is it? And why must my children celebrate it?" (129) In this place, Samad's minority views are given a platform, demonstrating that an alternate voice of the postcolonial "other" is also tolerated and respected. Glenard Oak, like O'Connell's Pool House and the playground, becomes a "contact zone" where diasporic characters and natives interact whilst preserving their distinct culture or embracing heterogeneity and hybridity. Ethnic minorities are not speechless, detached and marginalized here. These spaces/ places provide agency for the minorities as well as the diasporans. 
The novel constructs a picture of a much aspired cultural plurality by focusing on these local spaces and experiences. All these heterogeneous areas are animated by Smith's inside knowledge of British culture. The author uses realism similar to writers such as Honoré de Balzac, relating fiction to social geography, personal memories and experiences, to vividly articulate the small-scale cross-cultural encounters going on in these ordinary places, spaces and non-places.

Critics such as Paul Gilroy and Stuart Hall have underscored the impact of colonial history and the baggage of the past on the post-imperial London urban space and the diasporas within it. The structure and character analysis below further explore the significance of the past for the diaspora and the evolving spaces/places in which they live as will be examined in the next section.

\section{From "There" to "Now" and "Here": Transforming Diasporic Identity}

Locales are central to White Teeth. If London's spatiality emphasizes the present, then the "past" or history also cannot be undermined. The latter is an important feature of the diasporic identity in post-imperial London. Smith emphasizes the significance of the past as she begins the novel with an epigraph from The Tempest: "What's past is prologue," underlying that the present is an extension of the past. In the Shakespearean play, these words are originally uttered by Antonio, as he plans for a fresh start, rejecting the past and "relegating it to the dustbin of history where it will be powerless to influence the present" (Sell 29). Similarly, Sell argues that White Teeth "[...] heralds a fresh concern for a present disembarrassed of all complexes about historically determined origins and identities" (29). The characters' present and their identities are also uncannily structured by their past and histories,

But multiplicity is no illusion. Nor is the speed with which those in the simmeringmelting-pot are dashing towards it [...]. Because this is the other thing about immigrants ("fugees, émigrés, travellers"): they cannot escape their history anymore than you yourself can lose your shadow (WT 466).

These lines suggest that the past might "[...] have lost the crushing weight" (Sell 29), but the personal past and the history nevertheless continue to shape the present and simultaneously set the context for it. Moreover, the fragmented structure of the novel blends the present with the past. The chapters are structurally divided "Archie 1974, 1945," "Samad 1984, 1854," "Irie 1990, 1907” and "Magid, Millat, and Marcus 1992, 1999," disrupting the linear chronology and entangling the past and the present. The interplay between the narrative present and the resurgent past of the characters suggests that Smith intends to grasp the complexity of her diasporic characters in its totality. Moreover, the chapter names as "The Root Canals" of various characters refer to the significance of the past on a metaphoric level. Digging deep inside or into the past of the characters for a better present and future symbolizes the significance of finding one's cultural and racial background to decipher the complexity of the present existence. Besides, the non-linear narration, flashbacks, stream of consciousness and storytelling techniques, explain the recursive influence of the past on the present. Hence, White Teeth becomes a fertile ground for narrating inherited histories and re-enacting the past in the present. In addition, as a black British bildungsroman, if the spatial mapping of London in White Teeth focuses on the present of second generation diasporic 
characters such as Millat, Irie, Magid, then the other aspects of temporality such as the past (colonial and ancestral) and "there" (place of origin) are also not eschewed for the understanding of their transformed diasporic identity.

During the process of identity construction, the characters undergo several transitional stages. In an article, Smith employs a metaphor of language or voice to portray the normal transforming potential of cultural identity in Britain,

This voice I speak with these days, this English voice [...] is not the voice of my childhood. I picked it up in college. [...] It never occurred to me that I was leaving the London district of Willesden for Cambridge. I thought I was adding Cambridge to Willesden, this new way of talking to that old way. Adding a new kind of knowledge to a different kind I already had [...] I felt a sort of wonder at the flexibility of the thing. Like being alive twice.

Recently my double voice has deserted me for a single one [...] This voice I picked up along the way [...] now it is my only voice, whether I want it or not. I regret it; I should have kept both voices alive in my mouth. They were both a part of me. But how the culture warns against it! ("Tongues" 2009)

Smith's metaphor of the replacement of double voice by the new one signifies how British culture influences its subject and transforms it, and vice versa. Similarly, Irie is initially caught between the desire for the past and the need for freedom from her ethnicity so as to re-define herself. She forsakes her past and her heritage to adopt Chelfanism. But as she tries to construct her racial and sexual identity in London, she longs to discover her true identity which leads her to unravel her past and her roots. After her grandmother Hortense Bowden discloses the secrets of her parents, she begins to consider Jamaica her homeland. After a long period of turmoil, she finds it impossible to return to the past or to the original homeland, and she subsequently accepts her present and her identity as a person of mixed-race, and a working-class Londoner. The identity formation of this young and black woman in the novel reinforces Marc Stein's thesis on the transformed structure of bildungsroman in black British novels such as White Teeth. Furthermore, Alsana's aphoristic statement about the ambivalent lives of her children: "One leg in the present, one in the past. [...] Their roots will always be tangled" (80) succinctly sums up the confused lives of the second generation diasporans who are entangled between the past and the present. Despite the characters' preoccupation with the past, these micro-spaces/places/non-places plunge the novel back into the present, mundane life and "here." Like any other diasporic work, this novel does depict the overbearing past, the shattering experiences of cultural displacement and the sense of "in-betweenness," but its main focus is on cultural negotiation and assimilation in the land of birth or adoption. The novel White Teeth seems to primarily convey the message that the present, and being and belonging "here" is certainly more important than the past (colonial oppression, trauma of migration and racial discrimination) for the diaspora and this is achieved through spatial reconfiguration.

This paper has engaged with the various nuances of the twenty-first century vision of global and the post-imperial London's urbanscape as seen in White Teeth. It has (re)investigated psychological and socio-cultural aspects of the diasporic characters in the local spaces, places and non-places of this city. The article has also illustrated the complexities of mundane life in relation to the broader spatial configurations through complex and multifaceted literary reconfigurations of this city space. In other words, the inherent tension in the diasporic characters between the past/present and whether 
to belong to the original home or to the hostland, intensified in the aftermath of the British Empire, has been captured through the diverse micro-images of London's locales. This article has illustrated Smith's use of hybrid narrative technique to this effect. It has also portrayed transformed diasporic characters living in the convivial and multicultural spaces/places of the post-imperial London. By deconstructing binary discourse and power structures, these diverse spatial re-configurations have prepared us to look beyond the limiting categories of diaspora, such as race, origin, past and religion, towards an open, active and transformed multicultural spaces/places/non-places of London.

\section{Bhawana JAIN \\ University of Bourgogne Franche-Comté}

\section{Works Cited}

Alibhai-Brown, Yasmin. "A Magic Carpet of Cultures in London.” New York Times, 25 June 2000.

Appadurai, Arjun. "Disjuncture and Difference in the Global Cultural Economy." Theorizing Diaspora. Ed. Jana Evans Braziel and Anita Mannur. Oxford: Blackwell, 2003. 25-48.

Augé, Marc. Non-places: Introduction to an Antbropology of Supermodernity. London: Verso, 1995.

—. "Paris and the Ethnography of the Contemporary World." Parisian Fields. Ed. M. Sherringham. London: Reaktion, 1996. 175-8.

—. "Airports." City A-Z. Ed. S. Pile and N. Thrift. London: Routledge, 2000. 8-9.

BaudrilLard, Jean. Simulacres et Simulation. Paris: Galilée, 1981.

Beukema, Taryn. "Men Negotiating Identity in Zadie Smith's White Teeth." Postcolonial Text, 4.3 (2008): $1-15$.

BнавнA, Homi. The Location of Culture. London: Routledge, 1994.

—. "Culture's In-Between." Questions of Cultural Identity. Ed. Stuart Hall and Paul du Gay. London: Sage, 1996.

GILROY, Paul. After Empire: Melancholia or Convivial Culture? London: Routledge, 2004.

—. Postcolonial Melancholia. New York: Columbia UP, 2005.

Glissant, Édouard. Traité du Tout-Monde. Paris: Gallimard, 1997.

GuignerY, Vanessa. "Zadie Smith's NW: the Novel at an 'anxiety crossroads'?" Études britanniques contemporaines 45 (2013). 5 June 16 <http://ebc.revues.org/996>.

Hall, Stuart. "The New Ethnicities." Race, Culture and Difference. Ed. J. Donald and A. Rattansi. London: Sage, 1992.

-. An interview with Zoe Williams. "The Saturday interview: Stuart Hall." The Guardian, $11^{\text {th }}$ February 2012. 12 July 2015 <https://www.theguardian.com /theguardian/2012/feb/11/saturdayinterview-stuart-hall>

JAGGI, Maya. "In a Strange Land." The Guardian, 22 January 2000.

Mannu, Anita. Culinary fictions: Food in South Asian Diasporic Culture. Philadelphia: Temple UP, 2010.

Pile, Steve, and Nigel Thrift, eds. Mapping the Subject: Geograpbies of Cultural Transformation. New York: Routledge, 1995.

PRATT, Mary Louise. Imperial Eyes: Travel writing and Transcultration. New York: Rouledge, 1992.

Rutherford, J. “The Third Space: Interview with Homi Bhabha.” Identity: Community, Culture, Difference. London: Lawrence and Wishart, 1990. 222-35.

SelL, J. P. A. "Chance and Gesture in Zadie Smith's White Teeth and The Autograph Man: A Model for Multicultural Identity?" The Journal of Commonwealth Literature 41.3 (2006): 7-44.

Sмiтн, Zadie. White Teeth. London: Penguin, 2000.

-. "Speaking in Tongues." The New York Review of Books, 26 February 2009.

STEIN, Mark. Black British Literature: Novels of Transformation. Columbus: Ohio State UP, 2004. 